\title{
A rapid genome-wide response to Drosophila melanogaster social interactions Ginger E Carney
}

Address: Department of Biology, Texas A\&M University, College Station, TX, USA

Email: Ginger E Carney - gcarney@mail.bio.tamu.edu

Published: 22 August 2007

BMC Genomics 2007, 8:288 doi:10.1 | 86//47|-2164-8-288
Received: 22 December 2006

Accepted: 22 August 2007

This article is available from: http://www.biomedcentral.com/I47I-2/64/8/288

(c) 2007 Carney; licensee BioMed Central Ltd.

This is an Open Access article distributed under the terms of the Creative Commons Attribution License (http://creativecommons.org/licenses/by/2.0), which permits unrestricted use, distribution, and reproduction in any medium, provided the original work is properly cited.

\begin{abstract}
Background: The actions and reactions integral to mate recognition and reproduction are examples of multifaceted behaviors for which we are only beginning to comprehend the underlying genetic and molecular complexity. I hypothesized that social interactions, such as those involved in reproductive behaviors, would lead to immediate and assayable changes in gene expression. Such changes may have important effects on individual reproductive success and fitness through alterations in physiology or via short-term or long-term changes in nervous system function.

Results: I used Affymetrix Drosophila Genome arrays to identify genes whose expression profiles would change rapidly due to the social interactions occurring during Drosophila melanogaster courtship. I identified 43 loci with significant expression profile changes during a 5-min exposure period. These results indicate that social interactions can lead to extremely rapid changes in mRNA abundance.

Conclusion: The known functions of the up-regulated genes identified in this study include nervous system signaling and spermatogenesis, while the majority of down-regulated loci are implicated in immune signaling. Expression of two of the up-regulated genes, Odorant-binding protein $99 \mathrm{~b}$ (Obp99b) and female-specific independent of transformer (fit), is controlled by the Drosophila sexdetermination gene hierarchy, which regulates male and female mating behaviors and somatic differentiation. Therefore, additional identified loci may represent other long-elusive targets of Drosophila sex-determination genes.
\end{abstract}

\section{Background}

Social interactions are known to alter individual physiology, but the extent to which transcriptional or post-transcriptional mechanisms function in inducing these changes is unclear. Immediate responses are likely modulated by environmentally induced changes in synaptic signaling, which may result in alterations in gene expression with long-term consequences. Identifying the genetic basis for physiologic responses is of significant interest because it will clarify how regulated gene expression and the resulting intracellular signaling events modulate complex behaviors.

Genes that control complex traits such as behaviors are difficult to identify by standard mutant analysis for two major reasons: (1) behaviors may be influenced by a large number of genes which each have a small effect, and (2) the genes involved usually have pleiotropic functions dependent upon the cellular or developmental context. Despite these limitations, Drosophila geneticists have successfully used mutant analysis to identify loci integral to 
behaviors such as learning and memory, circadian rhythmicity, foraging and reproduction [Reviewed in [1]].

Newer technologies are also useful for gene discovery. Genomics approaches are widely used for identifying candidate behavior gene loci [2-9] that can be experimentally validated using other approaches. High throughput RNAi screens in cultured Drosophila cells have been used to identify genes involved in numerous cellular processes [Reviewed in [10]], and in vivo RNAi-based screens are now possible because of the recent creation of an RNAi Drosophila strain library [11]. These RNAi strains can be used to identify behavior genes by targeting specific cells, tissues and developmental periods.

Courtship behaviors in Drosophila are genetically programmed and require multi-modal inputs and outputs. Male flies use sight, smell, taste, and touch to identify appropriate mates [Reviewed in [12] and [13]] and learn to distinguish a conspecific female from a heterospecific female [14]. Females initially respond to male courtship advances by running away, but a female that receives and responds to appropriate signals from a courting male will allow herself to be mated, usually within 5-10 min.

Several major regulatory genes for $D$. melanogaster courtship and reproduction have been identified [Reviewed in $[12,13,15-17]]$, but only a small number of potential downstream targets are known [18-25]. The genes controlling reproduction as well as other behaviors can function during different time periods. Some of them may be required for development and differentiation of a sex-specific neural circuit. Recent work has placed fruitless (fru) into this category of genes [26-29]. The male-specific Fru protein directs development of a nervous system with male-specific neuron numbers and projections [27].

Other gene products may direct the function of the circuit by ensuring that the animal is primed to execute a behavior in response to environmental cues. fru also functions in this manner since inactivating fru neurons in adult males inhibits courtship behavior [28]. Finally, a third class that I refer to as "effector" genes should respond to the initiation or performance of a behavior to generate short-term and long-term changes in nervous system function and animal physiology. Genes in this group are expected to change expression as a consequence of behavioral responses. I hypothesized that loci in these three categories would be identifiable via whole genome assays of animals that recently performed a behavior of interest.

A recent microarray study in Drosophila suggested that there are differences in gene expression patterns between unexposed and courted (but unmated) females two hours after male exposure, indicating that the females respond at the genetic level to courtship [30]. Females also respond genetically to mating and the transferred male ejaculate $[30,31]$. Because courtship and mating occur quickly in Drosophila melanogaster, I reasoned that measurable changes in gene expression likely occur on a rapid timescale in flies as a consequence of pre-mating interactions. I tested this hypothesis by allowing virgin male flies to court, but not mate, virgin female flies during a 5-min interval and collecting whole-body RNA from the males to assay mRNA levels using Affymetrix Drosophila Genome Arrays. The results indicate that a small number of loci rapidly respond to these pre-mating interactions.

\section{Results \\ Courtship interactions cause rapid changes in mRNA abundance}

I exposed Drosophila melanogaster males to conspecific female courtship objects and tested male flies for rapid gene expression changes resulting from this social interaction. Single, four-day-old virgin male flies were allowed to court a virgin female for 5-min (See Methods). Only males that courted the female but did not mate during this time period were collected for RNA processing and microarray hybridization. The Drosophila Genome Arrays (Affymetrix version 1) used in these experiments contain probe sets for over 13,500 predicted transcripts based upon annotation of the Drosophila genome.

I used three data extraction methods (See Methods) to derive expression values that could be compared for statistically significant differences (I compared chips hybridized to labeled RNA from unexposed males to chips hybridized with labeled RNA from courting males). Only those genes statistically significant $(p<0.001)$ for at least two of the three data extraction methods are shown. The final data set comprises 43 genes with altered expression levels due to courtship interactions (Tables 1 and 2). Ten genes are up regulated, and 33 genes are down regulated based upon the described criteria. The majority of genes in the data set have p-values that are well below this cutoff (Tables 1 and 2).

\section{Validation of array results}

I chose a group of 4 up-regulated candidates and 9 downregulated candidates for further validation by Real-time PCR analysis (Table 3 ) and prepared cDNA from the RNA used for microarray hybridizations as well as from independently obtained samples. Relative expression levels from Real-time PCR were calculated separately for microarray samples and the independent samples. In each instance, genes with altered expression levels according to the microarray analysis also showed the same directional change when the array samples were re-tested by Realtime PCR (Table 3). 
Table I: Genes up regulated in courting males

\begin{tabular}{|c|c|c|c|c|c|}
\hline Gene identifier & Gene name & Avg. fold change & GCOS p-value & PM+MM p-value & PM only p-value \\
\hline CG6/28 & & 2.58 & $3.48 \mathrm{E}-04$ & 1.27E-04 & $1.93 \mathrm{E}-05$ \\
\hline CGI3155 & & 2.26 & & I.46E-04 & 6.27E-05 \\
\hline CG7738 & & 2 & 7.57E-04 & I.09E-06 & $3.22 \mathrm{E}-06$ \\
\hline CGI732 & & 1.89 & $7.29 E-04$ & $3.57 \mathrm{E}-05$ & $1.82 \mathrm{E}-04$ \\
\hline CG33060 & & 1.85 & $1.41 \mathrm{E}-04$ & I.35E-05 & $4.65 \mathrm{E}-05$ \\
\hline CG30042 & & 1.8 & $9.40 \mathrm{E}-04$ & $1.63 \mathrm{E}-05$ & $5.21 \mathrm{E}-04$ \\
\hline CG2958 & lectin-24Db & 1.71 & & 5.29E-04 & $6.01 \mathrm{E}-04$ \\
\hline CGI7820 & fit & 1.6 & $5.70 \mathrm{E}-04$ & $7.20 \mathrm{E}-05$ & I.10E-04 \\
\hline CG7592 & Obp99b & 1.52 & $2.44 \mathrm{E}-04$ & & 7.17E-04 \\
\hline CG7I06 & lectin-28C & 1.48 & 6.77E-04 & $3.46 \mathrm{E}-04$ & 2.IIE-04 \\
\hline
\end{tabular}

Ten genes are significantly $(\mathrm{p}<0.00 \mathrm{I})$ up regulated in males exposed to a conspecific female courtship object. The average fold change from microarray analysis is shown. The $\mathrm{p}$-values are from statistical analyses performed on expression values obtained by three different methods (See Methods).

Real-time PCR amplification from independent samples verified the increased expression of all four tested genes (CG1732, fit, Obp99b, lectin-28C) that were up regulated in exposed males according to the microarray analysis. The expression differences for fit and $O b p 99 b$ are statistically significant between the two treatments (Table 4).

Table 2: Genes down regulated in courting males

\begin{tabular}{|c|c|c|c|c|c|}
\hline Gene identifier & Gene name & Avg. fold change & GCOS p-value & PM+MM p-value & PM only p-value \\
\hline CG6639 & & -21.2 & $1.12 \mathrm{E}-10$ & $3.17 \mathrm{E}-10$ & I.24E-II \\
\hline CG4740 & AttC & -11.79 & $3.00 \mathrm{E}-07$ & $2.82 \mathrm{E}-05$ & $4.02 \mathrm{E}-04$ \\
\hline CGI8372 & AttB & -9.62 & & 3.19E-04 & 4.94E-04 \\
\hline CGI0I46 & $A t t A$ & -8.51 & 7.23E-04 & $3.80 \mathrm{E}-04$ & $6.72 \mathrm{E}-04$ \\
\hline CG4757 & & -7.69 & I.26E-07 & I.17E-06 & $1.65 \mathrm{E}-06$ \\
\hline CGI5066 & IM23 & -5.17 & I.IIE-08 & $1.13 \mathrm{E}-10$ & $1.61 \mathrm{E}-10$ \\
\hline CG8I75 & $M t k$ & -4.37 & 4.0IE-06 & I.88E-05 & $4.26 \mathrm{E}-05$ \\
\hline CGI367 & CecA2 & -4.31 & 8.34E-04 & $1.06 \mathrm{E}-05$ & $9.88 \mathrm{E}-04$ \\
\hline CGI3422 & & -4 & $3.16 \mathrm{E}-08$ & $2.34 \mathrm{E}-07$ & 3.7IE-07 \\
\hline CGI0810 & Drs & -3.99 & $8.60 \mathrm{E}-07$ & 7.77E-09 & $6.18 \mathrm{E}-09$ \\
\hline CGI08I6 & Dro & -3.3 & $2.73 \mathrm{E}-05$ & I.50E-08 & $3.13 \mathrm{E}-05$ \\
\hline CGI8563 & & -3.28 & $8.55 \mathrm{E}-06$ & I.57E-04 & $8.55 \mathrm{E}-06$ \\
\hline CGI365 & CecAl & -3.12 & 8.19E-04 & $4.65 \mathrm{E}-04$ & \\
\hline CG6687 & & -2.84 & 2.39E-04 & $4.02 \mathrm{E}-05$ & $6.84 \mathrm{E}-05$ \\
\hline CGI8I08 & $\mid M I$ & -2.46 & 8.67E-08 & $3.4 \mathrm{IE}-07$ & I.58E-07 \\
\hline CG9989 & & -2.18 & & I.00E-04 & 7. $14 \mathrm{E}-04$ \\
\hline CG5550 & & -1.93 & I.12E-04 & $1.26 \mathrm{E}-04$ & 2. $18 \mathrm{E}-05$ \\
\hline CG2217 & & -1.92 & & I.87E-05 & $2.42 \mathrm{E}-05$ \\
\hline CGI5065 & & -1.9 & 4.43E-05 & $9.75 \mathrm{E}-08$ & 7.54E-08 \\
\hline CGI4745 & PGRP-SC2 & -1.89 & & $4.30 \mathrm{E}-06$ & $6.96 \mathrm{E}-05$ \\
\hline CG9434 & Fst & -1.76 & & $3.46 \mathrm{E}-04$ & I.29E-04 \\
\hline CG2042 & & -1.67 & & I.40E-04 & 8.27E-05 \\
\hline CGI6772 & & -1.66 & 5.99E-04 & 3.7IE-05 & $2.53 \mathrm{E}-05$ \\
\hline CGI3947 & & -1.57 & $2.79 \mathrm{E}-04$ & $9.57 \mathrm{E}-05$ & 7.27E-05 \\
\hline CGI 8279 & $I M I O$ & -1.55 & $1.00 \mathrm{E}-03$ & $2.06 \mathrm{E}-05$ & $3.48 \mathrm{E}-05$ \\
\hline CGI3482 & & -1.48 & & $3.75 \mathrm{E}-04$ & 2.94E-04 \\
\hline CGI8I06 & IM2 & -1.42 & $5.99 \mathrm{E}-04$ & & $9.62 \mathrm{E}-04$ \\
\hline CGII992 & Rel & -1.42 & & $3.12 \mathrm{E}-04$ & 4.54E-04 \\
\hline CGI 6844 & IM3 & -1.4 & & 3.07E-06 & 7.87E-07 \\
\hline CGI523I & IM4 & -1.28 & & $9.52 \mathrm{E}-05$ & $4.92 \mathrm{E}-06$ \\
\hline CGI8067 & & -1.27 & & I.89E-05 & $9.24 \mathrm{E}-06$ \\
\hline CGI0332/IMI8 & & -1.05 & & $3.66 \mathrm{E}-04$ & $3.5 \mathrm{IE}-04$ \\
\hline CGI0947 & & -1.05 & & $2.74 \mathrm{E}-06$ & 4.20E-05 \\
\hline
\end{tabular}

Thirty-three genes are significantly $(p<0.001)$ down regulated in males exposed to a conspecific female courtship object. See the legend from Table I and Methods for a description of how the p-values were obtained. CGI0332 and IMI8 are overlapping transcription units that cannot be distinguished with the probe set on the Drosophila version I Genechip. 
Table 3: Real-time $P C R$ validation of microarray results

\begin{tabular}{|c|c|c|c|c|}
\hline Gene identifier & Gene name & Array fold change & Array RT-PCR & Independent RT-PCR \\
\hline CGI732 & & 1.89 & 2.94 & 2.86 \\
\hline CGI7820 & fit & 1.6 & 2.48 & 1.25 \\
\hline CG7592 & Obp99b & 1.52 & 1.51 & 1.35 \\
\hline CG7I06 & lectin-28C & 1.48 & 1.2 & 1.92 \\
\hline CGI6834 & lectin-33a & 1.87 & 5.37 & 4.91 \\
\hline CG4740 & AttC & -11.79 & -19.26 & -3.01 \\
\hline CG4757 & & -7.69 & -3.73 & 1.07 \\
\hline CGI5066 & IM23 & -5.17 & -6.46 & -1.07 \\
\hline CG8I75 & Mtk & -4.37 & -2.41 & 1.01 \\
\hline CGI367 & CecA2 & -4.31 & -3.75 & -1.04 \\
\hline CGI3422 & & -4 & -5.25 & 2.11 \\
\hline CGI0816 & Dro & -3.3 & -40.05 & -1.33 \\
\hline CG6687 & & -2.84 & -2.82 & 1.07 \\
\hline CG9434 & Fst & -1.76 & -2.79 & 1.6 \\
\hline
\end{tabular}

Five genes up regulated in courting males were verified by Real-time PCR on the samples used for array hybridization (Array RT-PCR) as well as by analysis of independently obtained samples (Independent RT-PCR). Nine down-regulated genes were validated using array samples, while 4 of 9 were validated on independent samples.

In contrast, not all of the down-regulated genes tested by Real-time PCR on independent samples showed the directional change predicted from the microarrays. However, a regression of mean expression fold-changes based on the microarray analysis versus mean fold-changes based on Real-time PCR of independently collected samples indicated a highly significant positive correlation between results obtained by the two methods $(\mathrm{r}=0.74, \mathrm{~N}=14$, $\mathrm{p}$ $=0.003)$. The p-values are non-significant when the down-regulated and up-regulated genes are considered separately. I attribute this result to the small sample size for each category, particularly since the genes with increased expression show the same trend in all analyzed samples. Thus, even though there is some error associated with the assays (see Discussion), the Real-time PCR results strongly support the microarray results.

\section{Up-regulated genes}

Genes with increased levels of expression due to reproductive interactions comprise a group with diverse functions as predicted by Gene Ontology (GO) annotations (Table $5)$. The two lectin genes, lectin-24Db and lectin-28C, are likely to function in spermatogenesis. A third lectin gene, lectin-33a, was identified as significantly up regulated (1.87-fold) only in the dChip PM-MM analysis, so it did not make the cut off. However, Real-time PCR confirms that lectin-33a is up regulated approximately 5-fold on average in the array and independent samples (Tables 3 and 4).

Most intriguingly, two previously identified targets of the sex-determination hierarchy, $O b p 99 b$ and fit [22], are up regulated in exposed males. Obp99b (also known as tsx) encodes an odorant binding protein that is enriched in adult male heads $[5,22]$ and is regulated by the sex-determination hierarchy genes, Sex-lethal $(S x l)$, transformer (tra), transformer-2 (tra-2) and doublesex (dsx) [22]. Although the specific functions of odorant binding proteins (Obps) are controversial, one possibility is that Obps are secreted into the olfactory sensillum and bind to and transport odorants to odorant receptors for downstream signal transduction [Reviewed in [32]]. Therefore, Obps may function in modulating olfactory responses to courtship.

Table 4: Relative expression levels of up-regulated candidate genes

\begin{tabular}{|c|c|c|c|}
\hline Gene identifier & Gene name & Unexposed males ( \pm SEM) & $\begin{array}{c}\text { Courtship-exposed males ( } \pm \\
\text { SEM) }\end{array}$ \\
\hline CGI732 & & $0.12 \pm 0.02$ & $0.32 \pm 0.1$ \\
\hline CGI7820* & fit $^{*}$ & $3.15 \pm 0.53$ & $5.21 \pm 0.6$ \\
\hline CG7592* & Obp99b* & $5.00 \pm 0.75$ & $7.00 \pm 1.52$ \\
\hline CG7I06 & lectin-28C & $0.67 \pm 0.08$ & $0.90 \pm 0.12$ \\
\hline CGI6834* & lectin-33a* & $0.24 \pm 0.1$ & $1.25 \pm 0.27$ \\
\hline
\end{tabular}

\footnotetext{
* indicates up-regulated genes with significantly different levels $(p<0.05)$ of expression when courtship-exposed and unexposed male samples are compared.
} 
Table 5: Predicted functions of up-regulated genes

\begin{tabular}{|c|c|c|c|c|}
\hline Gene identifier & Gene name & GO molecular function & GO biological process & Immune response \\
\hline CG6I28 & & alpha-L-fucosidase & $\begin{array}{l}\text { O-glycoside catabolism; } \\
\text { fucose metabolism }\end{array}$ & $\mathrm{n}$ \\
\hline CGI3I55 & & unknown & unknown & $\mathrm{n}$ \\
\hline CG7738 & & unknown & unknown & y \\
\hline CGI732 & & $\begin{array}{l}\text { GABA:sodium symporter } \\
\text { activity }\end{array}$ & ion transport & $n$ \\
\hline CG33060 & & Unknown function & unknown & $\mathrm{n}$ \\
\hline CG30042 & & unknown & unknown & $\mathrm{n}$ \\
\hline CG2958 & lectin-24Db & $\begin{array}{l}\text { galactose, fucose, mannose } \\
\text { binding }\end{array}$ & spermatogenesis & $\mathrm{n}$ \\
\hline CGI7820 & fit & unknown & unknown & $\mathrm{n}$ \\
\hline CG7592 & Obp99b & odorant binding & $\begin{array}{l}\text { autophagic cell death/ } \\
\text { olfactory behavior }\end{array}$ & $\mathrm{n}$ \\
\hline CG7I06 & lectin-28C & galactose binding & spermatogenesis & $\mathrm{n}$ \\
\hline
\end{tabular}

\section{Down-regulated genes}

Using the Gene Ontology database information available through Flybase, I determined the likely function of the genes with decreased expression in exposed males relative to unexposed controls (Table 6). Twenty-seven out of 33 genes with reduced abundance are loci previously implicated in innate immunity [33-37]. The functions of the remaining 6 genes are not known. Decreased expression of some immune response genes was supported by Realtime PCR (Table 3); however CG4757 was the only downregulated gene with a statistically significant difference in expression levels between the two treatments (See Methods). Given the general trend for immunity gene expression to be less abundant in courting males (Table 2) and previous observations indicating that mated males have decreased immunity [38], I hypothesize that a general but non-specific decrease in levels of immune response genes occurs in courting males.

\section{Discussion}

These findings indicate that short-term social interactions between flies can lead to rapid genetic responses. Two recent reports support the possibility of rapid changes in mRNA abundance, even within a 5-min interval. Yeast increases expression of approximately 2500 genes within 6 min of a change in environmental conditions [39]. Such rapid changes in mRNA abundance are not limited to single-celled organisms with small genes. The cichlid fish Astatotilapia burtoni can ascend to social dominance within minutes of being provided with environmental conditions that effect this change [40]. The transcription factor $e g r-1$ is rapidly induced in the brains of these fishes within a similarly short timeframe and may regulate genes that mediate long-term physiological effects of social dominance [40]. Other studies have shown that longer periods of behavioral stimulation can lead to changes in gene expression $[41,42]$, some of which are detected even 24 hr post-exposure $[6,43,44]$.
How are rapid changes in gene expression regulated? It is likely that transcriptional as well as post-transcriptional mechanisms are involved. In the case of stationary phase yeast, RNA Pol II appears to be located at the promoters for genes that are rapidly induced by changes in environmental conditions [39]. For metazoans such as flies, a similar regulatory mechanism can be used [Reviewed in [45]]. RNA Pol II pauses on the hsp70 promoter prior to heat-shock induction [46], and heat shock induces $h s p 70$ expression within 30-60 sec [47]. Heat shock also rapidly inhibits transcription of the histone $H 1$ gene [47].

Another possibility is that the increases or decreases in transcript abundance are due to post-transcriptional controls. Cells may respond to environmental stimuli by altering degradation patterns of specific transcripts, increasing or decreasing them as needed. Post-translational regulation of proteins via phosphorylation, for instance, may also account for part of the rapid response. Drosophila immune response genes are induced rapidly after a pathogen assault via post-translational activation of NF- $\kappa \mathrm{B}$ transcription factors [See ref [48]].

I identified a set of 43 loci with immediate alterations in mRNA abundance in male flies as a consequence of 5-min courtship interactions. Four of 10 up-regulated genes were retested and verified by Real-time PCR [Tables 3 and 4]. The up-regulated genes are involved in processes likely to be important for mating and reproduction such as neurotransmission (CG1732 and $O b p 99 b$ ) and spermatogenesis (lectin-24Db and lectin-28C). The three lectin genes are unique at the nucleotide level, so cross hybridization is unlikely to account for the fact that these genes were identified in my analysis. Lectin-24Db and Lectin-28C are possible paralogs of the accessory gland protein Acp $29 \mathrm{Ab}$ [49] that is transferred to females via the male ejaculate. Male flies, once they encounter a potential mate, may prepare to increase sperm and Acp production in anticipation 
Table 6: Predicted functions of down-regulated genes

\begin{tabular}{|c|c|c|c|c|c|}
\hline Gene identifier & Gene name & Location & $\begin{array}{l}\text { GO molecular } \\
\text { function }\end{array}$ & $\begin{array}{l}\text { GO biological } \\
\text { process }\end{array}$ & $\begin{array}{l}\text { Immune } \\
\text { response }\end{array}$ \\
\hline CG6639 & & $36 C 9$ & $\begin{array}{l}\text { chymotrypsin } \\
\text { activity }\end{array}$ & proteolysis & $y$ \\
\hline CG4740 & AttC & $50 \mathrm{~A} 3$ & unknown & $\begin{array}{l}\text { antibacterial } \\
\text { humoral response }\end{array}$ & $y$ \\
\hline CGI8372 & $A t t B$ & $5 \mathrm{ICI}$ & unknown & $\begin{array}{l}\text { antibacterial } \\
\text { humoral response }\end{array}$ & $y$ \\
\hline CGI0I46 & AttA & $5 \mathrm{ICl}$ & unknown & $\begin{array}{l}\text { antibacterial } \\
\text { humoral response }\end{array}$ & $y$ \\
\hline CG4757 & & 86D5 & carboxylesterase & unknown & $y$ \\
\hline CGI5066 & IM23 & $55 C 4$ & unknown & $\begin{array}{l}\text { antibacterial } \\
\text { humoral response }\end{array}$ & $y$ \\
\hline CG8I75 & Mtk & $52 \mathrm{Al}$ & unknown & $\begin{array}{l}\text { antibacterial/ } \\
\text { antifungal humoral } \\
\text { response }\end{array}$ & $y$ \\
\hline CGI367 & CecA2 & $99 \mathrm{E2}$ & unknown & $\begin{array}{l}\text { antibacterial } \\
\text { humoral response }\end{array}$ & y \\
\hline CGI3422 & & $57 A 4$ & glucosidase & $\begin{array}{l}\text { antibacterial defense } \\
\text { response }\end{array}$ & $y$ \\
\hline CGI08I0 & Drs & 63D2 & ion channel inhibitor & $\begin{array}{l}\text { antibacterial/ } \\
\text { antifungal humoral } \\
\text { response }\end{array}$ & $y$ \\
\hline CGI08I6 & Dro & $5 \mathrm{ICl}$ & unknown & $\begin{array}{l}\text { antibacterial } \\
\text { humoral response }\end{array}$ & $y$ \\
\hline CGI8563 & & $36 C 9$ & trypsin activity & proteolysis & $y$ \\
\hline CGI365 & CecAl & 99E2 & unknown & $\begin{array}{l}\text { antibacterial } \\
\text { humoral response }\end{array}$ & $y$ \\
\hline CG6687 & & $88 \mathrm{E} 3$ & $\begin{array}{l}\text { serine-type } \\
\text { endopeptidase } \\
\text { inhibitor; ATP } \\
\text { synthase }\end{array}$ & $\begin{array}{l}\text { ATP synthesis } \\
\text { coupled protein } \\
\text { transport; } \\
\text { proteolysis }\end{array}$ & y \\
\hline CGI8108 & $\mid M I$ & $55 C 4$ & unknown & defense response & $y$ \\
\hline CG9989 & & $98 \mathrm{EI}$ & unknown & unknown & $\mathrm{n}$ \\
\hline CG5550 & & 53DI0 & receptor binding & defense response & $y$ \\
\hline CG2217 & & $99 F 3-4$ & unknown & unknown & $\mathrm{n}$ \\
\hline CGI5065 & & $55 C 4$ & unknown & unknown & $y$ \\
\hline CGI4745 & PGRP-SC2 & 44E2 & $\begin{array}{l}\text { peptidoglycan } \\
\text { binding }\end{array}$ & defense response & $y$ \\
\hline CG9434 & Fst & $85 \mathrm{E} 2$ & unknown & response to cold & $y$ \\
\hline CG2042 & & 39DI & unknown & unknown & $\mathrm{n}$ \\
\hline CGI6772 & & $38 \mathrm{~A} 8$ & unknown & unknown & $\mathrm{n}$ \\
\hline CGI3947 & & 2 IE2 & unknown & unknown & $\mathrm{n}$ \\
\hline CGI8279 & $|M| O$ & $50 \mathrm{~A} 5$ & unknown & $\begin{array}{l}\text { antibacterial } \\
\text { humoral response }\end{array}$ & $y$ \\
\hline CGI3482 & & 70D5 & unknown & unknown & $y$ \\
\hline CGI8I06 & IM2 & $55 C 4$ & unknown & defense response & $y$ \\
\hline CGII992 & Rel & $85 C 3$ & transcription factor & defense response & $y$ \\
\hline CGI6844 & IM3 & $55 C 4$ & unknown & $\begin{array}{l}\text { antibacterial } \\
\text { humoral response }\end{array}$ & $y$ \\
\hline CGI523I & IM4 & $57 \mathrm{~B} 3$ & unknown & defense response & $y$ \\
\hline CGI8067 & & $57 A 5$ & unknown & unknown & $y$ \\
\hline CGI0332/IMI 8 & & $59 F 4$ & unknown & defense response & $y$ \\
\hline CGI0947 & & $38 C 6$ & unknown & unknown & $\mathrm{n}$ \\
\hline
\end{tabular}

Twenty-seven of the 33 down-regulated genes likely function in the immune response. CGI5065 is closely related to IM2. Immune responsive genes are overrepresented in this data set $\left(p=3.163 \times 10^{-32}\right.$, Fisher's Exact Test). 
of an imminent mating that will deplete ejaculate components.

None of the up-regulated candidates are known to interact with one another genetically or via protein-protein interactions, although 3 of the genes (CG13155, CG7738, lectin-33a) have predicted interaction partners from a yeast two-hybrid screen [50]. Only CG6128 has available alleles within the gene; both are P-element insertions within a very large upstream intron. Animals homozygous for the insertions are viable and fertile, which likely indicates that the insertions do not affect gene function.

Some of the candidates with increased expression are enriched in adult head tissue [51]. As expected from previously reported results [22], fit and Obp99b are enriched in head tissue but not in the brain [51]. CG1732 is expressed in the adult head (including the brain) and male accessory glands. Intriguingly, CG1732 is also enriched in larval fat body. CG7738 is enriched in the head, while CG33060 is expressed in the testis [51]. These expression patterns are consistent with my hypothesis that the candidates regulate reproductive behavior or sperm production.

Of particular interest from this study are the two previously identified targets of the Drosophila sex-determination hierarchy, $O b p 99 b$ and fit, which are sex-specifically expressed. The sex-determination genes control somatic sexual differentiation and sex-specific reproductive behaviors [Reviewed in [15]] and are expressed during development as well as in adult flies. $S x l$ regulates splicing of tra, which together with tra-2, directs sex-specific splicing of transcripts for fru and $d s x$. fru and $d s x$ encode transcriptional activator proteins $[52,53]$, but only a small number of targets for these factors have been identified [18-25]. fru is the major regulator of male sexual behavior [16] and directs male-specific neuronal development by regulating apoptosis as well as differentiation of neuronal processes $[27,29,54]$. Fru neuron function also is required in the adult male for numerous reproductive behaviors [28].

Sxl, tra and tra-2 regulate expression of Obp99b so that it is present at high levels only in males [22]. Loss-of-function mutations in Obp99b have not been reported, but females over expressing $O b p 99 b$ do not mate at wild-type frequency [22], possibly indicating that Obp99b has a behavioral function.

The second sex-determination target identified in this experiment, fit, is enriched in female heads in the fat body surrounding the brain and is regulated by the sex-determination gene $S x l$ but does not require tra or tra-2 function [20]; potential regulation of fit expression in males by the sex-determination hierarchy has not been examined. fit expression varies depending upon the genetic background; it is expressed at low levels in males of the $w^{1118}$ and $t r a-2 / C y O$ genotypes but is undetectable in Oregon- $R$ [22]. Levels of fit are elevated 2 hrs post mating (G.E.C. and L.L. Ellis, unpublished results). However, two hours after a courtship exposure, males that do not mate have fit levels similar to those of unexposed animals (G.E.C. and L.L. Ellis, unpublished results).

Interestingly, fit, Obp99b, and a third sex-determination target gene, takeout, are expressed in the fat body cells surrounding the adult brain [21,22], and Obp99b and takeout are expressed in the chemosensory systems of both sexes $[21,55]$. takeout has a known role in reproductive behavior; feminization of male takeout-expressing cells results in reduced courtship [21], and over expression of Obp99b in females affects their latency to copulation [22]. My Realtime PCR results indicate that a male-enriched takeoutrelated gene, CG5867 [21], is also up regulated in courting males compared to unexposed males (data not shown). Together, these results suggest that $O b p 99 b$ and fit also function in male reproduction and support previous work indicating that gene expression in the fat body of the head may have important functions in sex-specific reproductive behavior and physiology [21,22]. The fact that I identified at least two sex-determination target genes indicates that the expression changes are not simply due to differences in male activity levels.

I also report that 27 of 33 down-regulated genes are implicated in the innate immune response of flies. However, I was able to verify only a small number of the changes using independent samples (Table 3), and only one gene, CG4757, showed a statistically significant decrease in expression in courtship-exposed males (See Methods). While the trend indicates a general decrease in the transcript levels of immune response genes as a consequence of courtship interactions, the genes involved appear to be widely variable. Some down-regulated immunity genes are located at adjacent chromosome regions, possibly indicating that they are co-regulated. There are groups of immune genes at chromosome location 36C9 (CG6639, CG18563), 51C1 (AttA, AttB, Dro), 55C4 (IM1, IM2, IM3, IM23, CG15065) and 99E2 (CecA1, CecA2). The 55C region contains a head-specific cluster of co-regulated gene products [56]. The immune genes at 51C1, 55C 4 and 99E2 share sequence similarity (as do AttA and AttB with $A t t C)$, so partial cross-hybridization to probe sets may account for correlations among hybridization signals.

One possibility is that the immune system is not down regulated in this behavioral paradigm, and the assays are simply capturing a snapshot of the natural variation in immune response gene expression. An alternative hypothesis is that there is more than one way to rapidly down 
regulate the energetically costly immune response system. In this scenario, the specific genes are unimportant as long as resources previously spent bolstering the immune response are directed toward ensuring reproductive success. Since earlier work showed that mated males have decreased immunity that is correlated with the number of matings [38], it is plausible that males begin down-regulating immune response genes once mating appears likely. It is worth noting that antimicrobial peptides, similarly to $O b p 99 b$ and fit, are produced in the fat body, indicating that regulation of fat-body enriched transcripts throughout the body may play an important role in reproductive success.

Two other groups assayed the female genetic response to male courtship [30] or mating [30,31]. Somewhat surprisingly, both groups found that fit expression is increased in mated females [30,31]. In contrast to my results in males in which I find that immune response genes are generally down regulated, both groups observed increased expression of immune response loci in mated females [30,31].

\section{Conclusion}

I found that flies can rapidly alter gene expression patterns in the context of social interactions that occur during reproduction. Such changes in mRNA abundance are likely significant to individual reproductive success. Since the present experiment measured changes occurring in the entire male body, I likely missed many subtle changes such as those occurring in the central nervous system (CNS) or other tissues in only a small number of cells. Future experiments will be designed to identify additional potential candidates in the CNS as well as to differentiate between genes that are specific to reproductive behavior and those involved in more general social interactions among flies.

\section{Methods}

\section{Affymetrix Microarrays}

I collected virgin, wild-type Canton-S males and females and aged them at $25^{\circ}$ in groups of 20 or fewer flies. Males were transferred individually to new vials on day 3 . On day 4 a single female was aspirated into a vial containing a single male, and the pairs were observed for $5 \mathrm{~min}$ at $22^{\circ}$. Males for the unexposed treatment were mock aspirated.

Thirty-five percent of the males displayed robust courtship without mating (these animals were collected for RNA preparation), and $36 \%$ mated within the $5 \mathrm{~min}$ observation period. The remaining males (29\%) generally performed at least early courtship behaviors but did not attempt copulation. Males who demonstrated robust courtship toward the females (following, wing extension, copulation attempts) were collected, quick-frozen and stored at $-80^{\circ}$ for later RNA extraction. Only males who did not copulate during this 5-min window were collected. The time from completion of courtship to freezing was less than one minute for all samples.

Males were randomly pooled in groups of approximately 12 individuals, and total RNA was extracted in Trizol reagent (Invitrogen) following standard protocols. Control samples consisted of males that were treated identically except that they were not exposed to a courtship object. All collections and assays were performed at the same time each day to avoid circadian effects on gene expression.

Three RNA samples from males that courted females and three RNA samples from unexposed males were used to probe Drosophila Genome Arrays (Affymetrix version 1, based upon Berkeley Drosophila Genome Project v4.0) for a total of six arrays. RNA labeling and hybridization using standard Affymetrix protocols were performed at the University of Kentucky MicroArray Core Facility or at the Texas A\&M University Department of Biology Core Facility.

The statistical analysis of the six arrays (three experimental and three control) roughly followed that of Lawniczak and Begun [30]. Expression values were calculated by using three different methods: the method implemented in the GCOS software package (Affymetrix), the PM-only method of dChip [57] and the PM-MM method of dChip [57]. PM refers to a perfect match between the probe sequence and the Drosophila reference sequence, while MM (mismatch) refers to a single nucleotide difference between the probe and reference sequence that should affect RNA hybridization to the probe.

Each of these three sets of expression values was then analyzed separately with the Bayesian t-test implemented in Cyber-T [58]. In this experiment, groups of experimental and control animals were collected and analyzed in parallel, so I used Cyber-T's paired t-test option to test the null hypotheses of no change in expression level between exposed and unexposed males for each transcript represented on the microarray. For a transcript to be included in the analysis, I required it to display an expression value of at least 100 on at least three of the six experimental and control arrays. Following Lawniczak and Begun [30], I used $\mathrm{p}<0.001$ as a significance threshold to reject the null hypothesis. In general, I considered a transcript to exhibit a significant change in expression level only if it fulfilled these analysis criteria in at least two of the three separate statistical analyses (i.e., GCOS, dChipPM-MM, dChipPMonly). See Lawniczak and Begun [30] for a much more detailed discussion of this approach. 


\section{Real-time PCR}

To validate the microarray results, the Superscript $1^{\text {st }}$ Strand Synthesis Kit (Invitrogen) was used to prepare cDNA from independently obtained RNA samples (3 independent experimental and 3 independent control preparations) as well as from two sets of samples used for microarray analyses. I did not have sufficient RNA remaining from the third array sample to use for cDNA preparation.

cDNA preparations were diluted 1:15, and 1.5 ul was used in each reaction for Real-time PCR using the SYBR Green PCR Mastermix (Applied Biosystems) essentially as described previously [59]. Reactions were performed in the ABI7700 (Applied Biosystems) using the default run parameters.

I chose five up-regulated candidates for validation; however, only four of the primer pairs generated gene-specific amplification products (CG1732, fit, Obp99b, and lectin$28 C)$. Since most of the 33 down-regulated candidates are implicated in immune signaling, I chose a smaller number of candidates for PCR validation. I selected 9 genes that are not closely linked and are either uncharacterized or are known targets of each of the two major immune signaling gene cascades. Since Real-time PCR validated few of the down-regulated immune candidates, I did not continue to test additional genes from this group.

rp49 primers were used in control amplification reactions for normalizing the amount of cDNA in each preparation [59]. The Relative Standard Curve Method (Applied Biosystems) was used to determine relative levels of RNA for each sample. Values from female-exposed males were normalized to unexposed males to derive an average fold change in expression.

Each experiment included control reactions for each primer pair to test for amplification specificity in the presence or absence of template. A melting curve analysis was performed at the end of each run to test for primer specificity. As a second test for presence of the correct product, selected reactions were electrophoresed on agarose gels to view PCR amplification products.

I calculated the fold change for the Genechip hybridization samples independently from the three samples that were used only for Real-time PCR confirmation. All of the up-regulated genes tested had the expected directional increase. I grouped the 5 sets of samples together for statistical analysis in order to increase the sample size for the comparisons and performed a two-tailed t-test. Levels of fit, Obp99b, and lectin-33a and are significantly different ( $\mathrm{p}<0.05$ ) between the unexposed and exposed treatments, and all 3 genes are up regulated by courtship expo- sure. While the levels of CG1732 and lectin-28C are consistently higher in courtship-exposed males compared to mock-exposed males, the two treatments are not statistically different from one another. I attribute this finding to the small sample size and the variation in the absolute levels of transcripts among the different samples for a particular treatment. The levels of one down-regulated gene, CG4757, are significantly different $(\mathrm{p}<0.05)$ between the exposed and unexposed males.

\section{Authors' contributions}

GEC conceived and executed the experiments, participated in the data analysis and wrote the manuscript.

\section{Acknowledgements}

I thank Ms. Donna Wall and Dr. Kuey-Chu Chen at the University of Kentucky MicroArray Core Facility for sample labeling and hybridization. I also thank Dr. Adam Jones for assistance with data analysis and helpful discussions on experimental design. I thank two anonymous reviewers for their thoughtful comments. This work was supported by funds provided to G.E.C. by Texas A\&M University.

\section{References}

I. Sokolowski MB: Drosophila: Genetics meets behavior. Nat Rev Genet 200I, 2:879-890.

2. Ben-Shahar Y, Robichon A, Sokolowski MB, Robinson GE: Influence of gene action across different time scales on behavior. Science 2002, 296:74I-744.

3. Ceriani MF, Hogenesch JB, Yanovsky M, Panda S, Straume M, Kay SA: Genome-wide expression analysis in Drosophila reveals genes controlling circadian behavior. J Neurosci 2002, 22:9305-9319.

4. Toma DP, White KP, Hirsch J, Greenspan RJ: Identification of genes involved in Drosophila melanogaster geotaxis, a complex behavioral trait. Nat Genet 2002, 3 I :349-53.

5. Anholt RRH, Dilda CL, Chang S, Fanara J-J, Kulkarni NH, Ganguly I, Rollmann SM, Kamdar KP, Mackay TFC: The genetic architecture of odor-guided behavior in Drosophila: epistasis and the transcriptome. Nat Genet 2003, 35:180-184.

6. Dubnau J, Chiang A-S, Grady L, Barditch J, Gossweiler S, McNeil J, Smith P, Buldoc F, Scott R, Certa U, Broger C, Tully T: The staufenl pumilio pathway is involved in Drosophila long-term memory. Curr Biol 2003, 13:286-296.

7. Grozinger CM, Sharabash NM, Whitfield CW, Robinson GE: Pheromone-mediated gene expression in the honey bee brain. Proc Natl Acad Sci U S A 2003, I 00(Suppl 2): 145| 9-25.

8. Aubin-Horth N, Landry CR, Letcher BH, Hofmann HA: Alternative life histories shape brain gene expression profiles in males of the same population. Proc $R$ Soc $B$ 2005, 272: $1655-1662$.

9. Mackay TFC, Heinsohn SL, Lyman RF, Moehring AJ, Morgan TJ, Rollmann SM: Genetics and genomics of Drosophila mating behavior. Proc Natl Acad Sci USA 2005, 1 02:6622-6629.

10. Perrimon N, Mathey-Prevot B: Applications of high-throughput RNA interface screens to problems in cell and developmental biology. Genetics 2007, 175:7-16.

II. Dietzl G, Chen D, Schnorrer F, Su K-C, Barinova Y, Fellner M, Gasser B, Kinsey K, Oppel S, Scheiblauer S, Couto A, Marra V, Keleman K, Dickson BJ: A genome-wide transgenic RNAi library for conditional gene inactivation in Drosophila. Nature 2007, 448: $15 \mid-156$.

12. Greenspan RJ, Ferveur J-F: Courtship in Drosophila. Ann Rev Genet 2000, 34:205-232.

13. Billeter J-C, Goodwin SF, O'Dell KMC: Genes mediating sex-specific behaviors in Drosophila. Adv Genet 2002, 47:87-116.

14. Dukas R: Male fruit flies learn to avoid interspecific courtship. Behav Ecol 2004, 15:695-698.

15. Cline TW, Meyer BJ: Vive le difference: males vs females in flies vs worms. Ann Rev Genet 1996, 30:637-702. 
16. Baker BS, Taylor BJ, Hall JC: Are complex behaviors specified by dedicated regulatory genes? Reasoning from Drosophila. Cell 200I, I05:13-24.

17. Christiansen AE, Keisman EL, Ahmad SM, Baker BS: Sex comes in from the cold: the integration of sex and pattern. Trends Genet 2002, 18:510-516.

18. Burtis KC, Coschigano KT, Baker BS, Wensink PC: The Doublesex proteins of Drosophila melanogaster bind directly to a sexspecific yolk protein gene enhancer. EMBO J I99|, 10:2577-2582

19. Cann MJ, Chung E, Levin R: A new family of adenylyl cyclase genes in the male germline of Drosophila melanogaster. Dev Genes Evol 2000, 2 1 0:200-206.

20. Kopp IA, Carroll SB: Genetic control and evolution of sexually dimorphic characters in Drosophila. Nature 2000, 408:553-559.

21. Dauwalder B, Tsujimoto S, Moss J, Mattox W: The Drosophila takeout gene is regulated by the sex determination pathway and affects male courtship behavior. Genes Dev 2002, 1 6:2879-2892.

22. Fujii S, Amrein H: Genes expressed in the Drosophila head reveal a role for fat cells in sex-specific physiology. $E M B O$ 2002, 2 I:5353-5363.

23. Bray S, Amrein H: A putative Drosophila pheromone receptor expressed in male-specific taste neurons is required for efficient courtship. Neuron 2003, 39:1019-1029.

24. Drapeau MD, Radovic A, Wittkopp PJ, Long AD: A gene necessary for normal male courtship, yellow, acts downstream of fruitless in the Drosophila melanogaster larval brain. I Neurobiol 2003, 55:53-72.

25. Arbeitman MN, Fleming AA, Siegal ML, Null BH, Baker BS: A genomic analysis of Drosophila somatic sexual differentiation and its regulation. Development 2004, I 3 I:2007-202 I.

26. Demir E, Dickson BJ: fruitless specifies male courtship behavior in Drosophila. Cell 2005, I $21: 785-794$.

27. Kimura K-I, Ote M, Tazawa T, Yamamoto D: Fruitless specifies sexually dimorphic neural circuitry in the Drosophila brain. Nature 2005, 438:229-233.

28. Manoli DS, Foss M, Villella A, Taylor BJ, Hall JC, Baker BS: Male specific fruitless specifies the neural substrates of Drosophila courtship behaviour. Nature 2005, 436:395-400.

29. Stockinger P, Kvitsiani D, Rotkopf S, Tirian L, Dickson BJ: Neural circuitry that governs Drosophila male courtship behavior. Cell 2005, I 2 I:795-807.

30. Lawniczak MKN, Begun DJ: A genome-wide analysis of courting and mating responses in Drosophila melanogaster females. Genome 2004, 47:900-910.

31. McGraw LA, Gibson G, Clark AG, Wolfner MF: Genes regulated by mating, sperm, or seminal proteins in mated female Drosophila melanogaster. Curr Biol 2004, I4: I509-I5|4.

32. Rützler M, Zwiebel LI: Molecular biology of insect olfaction: recent progress and conceptual models. I Comp Physiol A Neu roethol Sens Neural Behav Physiol 2005, 1 91 :777-790.

33. De Gregorio E, Spellman PT, Rubin GM, Lemaitre B: Genome-wide analysis of the Drosophila immune response by using oligonucleotide microarrays. Proc Natl Acad Sci USA 2001, 98: $12590-12595$

34. Irving P, Troxler L, Heuer TS, Kopczynski C, Reichert J-M, Hoffmann JA, Hetru C: A genome-wide analysis of immune responses in Drosophila. Proc Natl Acad Sci USA 2001, 98: I5। I9-15I 24.

35. Boutros $M$, Agaisse $H$, Perrimon N: Sequential activation of signaling pathways during innate immune responses in Drosophila. Dev Cell 2002, 3:71 I-722.

36. De Gregorio E, Spellman PT, Tzou P, Rubin GM, Lemaitre B: The Toll and Imd pathways are the major regulators of the immune response in Drosophila. EMBO J 2002, 2 I:2568-2579.

37. Park JM, Brady H, Ruocco MG, Sun H, Williams D, Lee SJ, Kato T Jr, Richards N, Chan K, Mercurio F, Karin M, Wasserman SA: Targeting of TAK I by the NF-kappa B protein Relish regulates the JNK-mediated immune response in Drosophila. Genes Dev 2004, 1 8:584-94.

38. McKean KA, Nunney L: Increased sexual activity reduces male immune function in Drosophila melanogaster. Proc Natl Acad Sci USA 200I, 98:7904-7909.

39. Radonjic M, Andrau J-C, Lijnzaad P, Kemmeren P, Kockelkorn TTJP van Leenen D, van Berkum NL, Holstege FCP: Genome-wide analyses reveal RNA polymerase II located upstream of genes poised for rapid response upon $S$. cerevisiae stationary phase exit. Mol Cell 2005, 18:17|-183.

40. Burmeister SS, Jarvis ED, Fernald RD: Rapid behavioral and genomic responses to social opportunity. PLoS Biol 2005, 3(I I):e363-.

4I. Irwin LN: Gene expression in the hippocampus of behaviorally stimulated rats: analysis by DNA microarray. Molec Brain Res 2001, 96:163-169.

42. Bradley KC, Boulware MB, Jiang H, Doerge RW, Meisel RL, Memelstein PG: Changes in gene expression in the nucleus accumbens and striatum following sexual experience. Genes Brain Behav 2005, 4:3I-44.

43. Cavallaro S, Schreurs BG, Zhao W, D'Agata V, Alkon DL: Gene expression profiles during long-term memory consolidation. Eur J Neurosci 2001, 13:1809-1815.

44. Cavallaro S, D'Agata V, Manickam P, Dufour F, Alkon DL: Memoryspecific temporal profiles of gene expression in the hippocampus. Proc Natl Acad Sci USA 2002, 99: I6279-I6284.

45. Saunders A, Core LJ, Lis JT: Breaking barriers to transcription elongation. Nat Rev Mol Cell Biol 2006, 7:557-567.

46. Gilmour DS, Lis JT: RNA Polymerase II interacts with the promoter region of the noninduced hsp70 gene in Drosophila melanogaster cells. Mol Cell Biol 1986, 6:3984-3989.

47. O'Brien T, Lis JT: Rapid changes in Drosophila transcription after an instantaneous heat shock. Mol Cell Biol 1993 I 3:3456-3463.

48. Hoffmann JA: The immune response of Drosophila. Nature 2003, 426:33-38

49. Holloway AK, Begun DJ: Molecular evolution and population genetics of duplicated accessory gland protein genes in Drosophila. Mol Biol Evol 2004, 2 I: |625-1628.

50. Giot L, Bader JS, Brouwer C, Chaudhari A, Kuang B, Li Y, Hao YL, Oo CE, Godwin B, Vitols E, Vijayadamodar G, Pochart P, Machineni H, Welsh M, Kong Y, Zerhusen B, Malcolm R, Varrone Z, Collis A, Minto M, Burgess S, McDaniel L, Stimpson E, Spriggs F, Williams J, Neurath K, loime N, Agee M, Voss E, Furtak K, Renzulli R, Aanensen N, Carrolla S, Bickelhaupt E, Lazovatsky Y, DaSilva A, Zhong J, Stanyon CA Finley RL, White KP, Braverman M, Jarvie T, Gold S, Leach M, Knight J, Shimkets RA, McKenna MP, Chant J, Rothberg JM: A protein interaction map of Drosophila melanogaster. Science 2003 302:1727-1736

51. Chintapalli VR, Wang J, Dow JAT: Using FlyAtlas to identify better Drosophila models of human disease. Nat Genet 2007 39:715-720.

52. Erdman SE, Burtis KC: The Drosophila doublesex proteins share a novel zinc finger related DNA binding domain. EMBO J 1993, I 2:527-536.

53. Ryner LC, Goodwin SF, Castrillon DH, Anand A, Villella A, Baker BS, Hall JC, Taylor BJ, Wasserman SA: Control of male sexual behavior and sexual orientation in Drosophila by the fruitless gene. Cell 1996, 87:1079-1089.

54. Billeter J-C, Villella A, Allendorfer JB, Dornan AJ, Richardson M, Gailey DA, Goodwin SA: Isoform-specific control of male neuronal differentiation and behavior in Drosophila by the fruitless gene. Curr Biol 2006, I 6:1063-1076.

55. Galindo K, Smith DP: A large family of divergent Drosophila odorant-binding proteins expressed in gustatory and olfactory sensilla. Genetics 200 I, I 59:1059-1072.

56. Boutanaev AM, Kalmykova Al, Shevelyov, Nurminsky DI: Large clusters of co-expressed genes in the Drosophila genome. Nature 2002, 420:666-669.

57. Li J, Wong L: Emerging patterns and gene expression data. Genome Inform 2001, I 2:3-13.

58. Baldi P, Long AD: A Bayesian framework for the analysis of microarray expression data: regularized t-test and statistical inferences of gene changes. Bioinformatics 2001, I 7:509-5I9.

59. Carney GE, Taylor B]: logjam encodes a predicted EMP24/GP25 protein that is required for Drosophila oviposition behavior. Genetics 2003, 164:173-186. 